\title{
Temporary Employment and the Future Labor Market Status
}

\section{Tomas Berglund'}

Professor, University of Gothenburg, the Department of Sociology and Work Science, Sweden

1 Kristina Håkansson

Professor, University of Gothenburg, the Department of Sociology and Work Science, Sweden

1 Tommy Isidorsson

Associate Professor, University of Gothenburg, the Department of Sociology and Work Science, Sweden

\section{Johan Alfonsson}

PhD Student, University of Gothenburg, the Department of Sociology and Work Science, Sweden

\begin{abstract}
The aim of this article is to describe and explain the development of temporary employment in Sweden between 1992 and 2010, and to investigate the effect of temporary employment for individuals' future career on the labor market. The article analyzes temporary employees' status transitions on the labor market using Swedish Labour Force Survey (LFS) data for the period 1992-2010. Each cohort consists of 2-year panels and focuses on changes between the first and last measuring points. The findings indicate that the specific type of temporary employment is crucial as regards whether or not it constitutes a stepping-stone toward permanent employment. The chances are greater in the case of, for example, substitutes, but are considerably less in the case of on-call employment. Certain types of temporary employment thus seem to be used by the employer to screen the employability of the employee, while others are used for achieving flexibility.
\end{abstract}

\section{KEYWORDS}

Labor market situation / longitudinal study / Sweden / temporary employment

DOI

To be announced

emporary employment is often designated as an atypical form of employment. For young people, however, this is rather a typical form of employment. In Sweden, more than half of all workers aged between 15 and 24 are temporary employees. The likelihood of ending up in temporary employment also depends on, for example, country of birth, professional group, number of working hours, and sector. One important societal

\footnotetext{
${ }^{1}$ Corresponding author: Tomas Berglund, Department of Sociology and Work Science, Skanstorget 18, Box 720, SE-405 30 Gothenburg, Sweden. E-mail: Tomas.Berglund@socav.gu.se.
}

A shorter Swedish version of this article will be published in Arbetsmarknad \& Arbetsliv spring 2017. 
issue, then, is how temporary this working situation is and what happens after having worked as a temporary employee. In the political debate, the trade unions emphasize the insecure conditions of this form of employment, while the employers advocate it as a good way of entering the labor market - temporary employment is being seen as a stepping stone toward a permanent job. Sweden is an interesting case for studying temporary employment since the proportion of temporary employees is high and the regulation of temporary contracts stands out as the most liberal among the Nordic countries. Thus, it seems that temporary contracts are normalized on the Swedish labor market. In this article, we will shed light on what actually happens to temporary employees in Sweden. Under which prerequisites will a temporary employment lead to a permanent job? And when will temporary employment instead lead to unemployment, to becoming self-employed, or to leaving the labor force?

In a European perspective, Sweden has a high proportion of temporary employees, ranking 8th of 34 European countries in 2015 (Eurostat, 2016). In a Nordic context, Sweden and Finland are characterized by significantly higher levels than Denmark and Norway (Berglund et al., 2010). Historically, the proportion of temporary employees has slowly been increasing in Sweden since measurements started at the end of the 1980s (SCB, 2015, p. 37). This increase primarily occurred during the 1990s, from a level of approximately $10 \%$ at the beginning of the decade to approximately $16 \%$ in 1999 . Following that, the level was rather stable (approximately 15\%) until the second half of the 2000 s, when an increase occurred right up until 2007 , then peaking at just over $17 \%$. The most recently available figure from Statistics Sweden (SCB) is $16.5 \%$ for 2015 .

The statistics thus show a strong increase since the start of the 1990s. But exactly which types of temporary employment have increased and what does this mean for the possibility of getting a permanent job?

The aim of this article is to describe and explain the development of temporary employment in Sweden between 1992 and 2010, and to investigate the effect of temporary employment for the future labor market status. To what extent does a temporary job lead to a permanent job, to unemployment, to becoming self-employed, or to leaving the labor force? Which factors can explain the different outcomes?

Our main theoretical contribution is that we elaborate on the understanding of the multitudinous aspects of temporary employment. By distinguishing between different kinds of temporary employment- which reflect the employers' motives for using temporary contracts - this article contributes to the understanding of when a temporary contract works as a stepping stone to permanent contract. Furthermore, we analyze the long-term development of temporary contracts and use this knowledge in the contextualization of the results. Thus, this article contributes to a multilevel analysis of the effect of a temporary employment for the future labor market situation of the individual.

\section{Regulating temporary employments}

In parallel with the increase in the proportion of temporary employees, the Swedish legislation has also gradually been loosened up (Swedish Code of Statutes, 1982:80). The changes made to the Employment Protection Act, since its inception in 1974, have almost always concerned simplified possibilities of using temporary employment, while few changes have been made for permanent contracts. In 1982, the Act was changed in

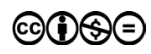


order to allow more occasions to use temporary employment, that is, probation and for backlogs of work. The latter form of employment was, however, limited to a maximum period of 6 months in any 2-year period. In 1997, the Act was relaxed slightly through the addition of the possibility for employers, without any special reason, to employ up to five persons, known as Agreed Temporary Employment. At the same time, possibilities for substitutes to gain permanent employment were augmented. An employee who had worked as a substitute for one employer for a total of more than 2 years in any 5 -year period would gain permanent employment.

A decade later, in 2007, a major change was made to the Act through the advent of General Temporary Employment (GTE). This legislative change means that the employer can have an unlimited number of temporary contracts without any special reason. While the change to the Act makes it easier for the employer to hire staff on temporary contracts, it also aimed at providing the temporary employee with increased security. Employees who are employed on a GTE contracts for one employer for a total of more than 2 years in a 5 -year period will gain a permanent employment contract. The legislation is semi-dispositive, entailing that the parties can restrict it or sign away this element.

This new form, GTE, replaced several different types of temporary employments, as in the case of backlogs, limited duration, specific work, and Agreed Temporary Employment. The types now specified in the Act also include, besides GTE, substitutes, probationary employment, seasonal work, and when employees have turned 67 (Swedish Code of Statutes, 1982:80, Sections 5 and 6). Even though the legislative changes in 2007, regarding GTE, were intended to provide temporary employees with enhanced protection in the form of the right to permanent employment under certain conditions, this entailed, in practice, opportunities for employers to 'stack' different temporary employments end-to-end. In doing so, employees might initially be employed as substitutes for just under 2 years and subsequently be given GTE for just under 2 years with the same employer and then, after a brief break in their employment, employees would have to restart their 2-year qualifying period for a permanent employment position. In order to deal with this, there was an adjustment to the law (Swedish Code of Statutes, 2016:248) in 2016 that slightly restricted the employer's possibilities to via a short interruption in the GTE contract circumvent employees' possibilities to qualify for permanent employment contract. The new amendment disregards periods shorter than 6 months without employment when determining the 5 -year period.

An analysis of the OECD index on the strictness of employment protection (the EPL index) shows that, in Sweden, there has been a considerable liberalization of the regulations governing the use of temporary contracts over the past 25 years. The legislative changes in 2007 meant that Sweden's ranking on the EPL index fell from 1.44 to 0.81 with only UK, Iceland, and Ireland with laxer employment protection for temporary contracts among 25 European countries in 2013 (OECD, 2016). The corresponding score for Norway was 3.00 (23rd) in 2013, while Denmark and Finland scored 1.38 (11th) and 1.56 (13th), respectively. In 2013, the OECD countries had an average value of 1.72. It should also be mentioned that the Swedish EPL index for temporary employees in 1990 was 4.08. The Swedish EPL index for permanent employees has not changed appreciably since the 1970s when the act was introduced, and since 1990, it only fell from 2.8 to 2.6 in 2013. On average, the OECD countries fell from 2.23 to 2.04 during the same period. The three Scandinavian countries Norway, Finland, and Denmark 
have a slightly lower EPL index, but still over the OECD average for regular contracts. In an international perspective, Sweden has one of the largest differences in employment protection between regular and temporary contracts; thus, Sweden has clearly chosen to increase numerical flexibility by giving employers greater opportunities to employ on temporary contracts, while keeping the protection for regular employees. This has also been noted in international research, for example, by Kathleen Thelen (2014, p. 188), who is of the opinion that Sweden is strongly risking the rise of a dual labor market.

\section{Previous research}

The possibilities for individuals to be established on the labor market through temporary employment can be understood and analyzed by theories regarding employers' motives in using temporary employment, and by theories regarding changes in trade cycle and institutional conditions across time.

\section{Employers' motives as an explanation}

When it comes to theories regarding employers' motives, temporary contracts can be envisaged as having two general functions. Firstly, they can create an opportunity for the employer to 'screen' the more difficult-to-measure aspects of a job searcher's employability, for example, his/her motivation (Gash, 2008; Korpi \& Levin, 2001). From such a perspective, generally every form of temporary employment is seen as a kind of probationary employment. According to Gash (2008), this should primarily apply to more qualified jobs due to the high transaction costs involved in seeking that kind of information. The theory implies that temporary employment must primarily be seen as a step toward a more established position on the labor market.

The second function is when the employer uses this form of employment for reasons of flexibility (Gash, 2008; Houseman, 2001). Temporary employment thus creates numeric flexibility in institutional contexts with strong protection for regular permanent employment. This can lead to a segmenting of the labor market, through which groups with low human capital have slight possibilities of becoming more stably established, through a permanent employment contract, while people with more coveted qualifications are protected within the organizational core of employees (Barbieri, 2009; Kalleberg, 2003).

\section{Temporary employment as a stepping-stone or a blind alley for the individual?}

With regard to Swedish empirical research seeking to determine whether or not temporary employment is a way into permanent employment, a small number of studies exist, the bulk of which are based on data from the 1990s or early 2000s. Levin (1998) has compared the risk for temporary and permanent employees of becoming unemployed and found that temporary employees have an approximately four times greater risk. Levin does not, however, analyze different types of temporary employment. Håkansson 
(2001) points out that the specific type of temporary employment is one important explanation as regards whether or not the temporary employee will establish him-/herself on the labor market later on via permanent employment. This study shows that temporary employment aimed at giving the employer numeric flexibility, for example, on-call and seasonal employment, to a greater extent leads to an uncertain labor market situation. These categories of temporary employees find it difficult to establish themselves on the labor market, to a greater extent suffering from periods of unemployment interspersed with periods of work. Temporary employment becomes, in these cases, a blind alley. Substitutes and project workers, on the other hand, can be seen as a way for the employer to acquire important competence (and as a kind of probationary employment), and can to a greater extent lead to stable establishment on the labor market. Håkansson’s (2001) study also showed that men had considerably greater opportunities to establish themselves on the labor market following temporary employment; this was also the case after control for industry, training, and type of temporary employment.

During recent years, the so-called stepping-stone hypothesis has been tested empirically in several countries. These studies focus on the individual and investigate whether or not temporary employment constitutes a stepping-stone to permanent employment during transitions from, for instance, unemployment or studies. Via this stepping-stone, the chance of gaining permanent employment is assumed to increase. A comparative analysis of temporary employees' transition to permanent contract shows large differences between EU-countries (OECD, 2014; 182). Except for a few countries, less than $50 \%$ of the temporary employees a given year had got permanent contracts 3 years later. However, these figures did not control for any individual factors. There are also several national studies testing the stepping-stone hypothesis, but it is difficult to draw any general conclusions from these studies, as they were conducted in different institutional contexts. Some differences within the temporary employee group are, however, of interest to highlight. Several studies point to the significance of differentiating between different types of temporary employment (Berton et al., 2011; Booth et al., 2002; Håkansson, 2001). The different types of temporary employments function differently for the employer, but differ also as regards opportunities for competence development, which in turn affects employability. A Norwegian study has shown, however, that there are no differences between the different types of temporary employment (Nergaard, 2004). Further, several studies have investigated whether or not the possibility of gaining permanent employment differs between men and women. There are no unequivocal findings here either. Neergaard (2016), who uses LFS data in Norway, finds that gender, age, and education are insignificant. Booth et al. (2002) found that men who establish themselves on the UK labor market via temporary employment fall behind in wage growth for a long time. This wage gap does not apply to women. Buddelmeyer and Wooden (2011) found major gender differences regarding the possibility of temporary employed to become established on the labor market in Australia. For men, these type of contracts work as a stepping-stone toward establishment on the labor market to a greater degree than for women.

Mooi-Reci and Dekker (2015), in a longitudinal study, compared the risk of becoming unemployed between temporary and permanent employees in the Netherlands. They show that those who have previously been temporary employed have recurring periods of unemployment to a greater extent. The explanation, according to the authors, lies in the employer's view of temporary employees as a secondary workforce, suited to less 
qualifying jobs that are not intended to be permanent. Reichelt's (2015) longitudinal study of temporary employees in Germany also shows that low-qualified jobs have a buffer-function, and therefore to a minor extent leading to permanent jobs. Reichelt found that employees in medium-qualified jobs had the greatest chance of staying in work. Neither Reichelt nor Mooi-Reci and Dekker differentiate, however, between different types of temporary employment; the result is assumed to apply to the entire group regardless of the type of temporary employment.

\section{Institutional and business cycle explanations}

Temporary employees' possibilities of establishing themselves can also depend on legislative changes and the state of the business cycle. Previous research has shown, for example, how the legalization of employment agencies has changed employers' staffing strategies (Bergström et al., 2007). The regulation of both temporary and permanent employment is an important institutional factor to take into account. Previous research has shown that liberal regulation of temporary contracts in combination with strong protection for permanent contracts correlates with a high proportion of temporary employees (OECD, 2004; Hevenstone, 2010). However, a study of the mobility of temporary employees in countries with different degrees of regulation shows no clear pattern. The level of mobility was high both in the UK, which is characterized by very liberal employment protection legislation, and in Spain, which in contrast has very strict legislation (Leschke, 2009 , p. 708). Temporary employees' possibilities of establishing themselves on the labor market have, however, shown themselves to be more difficult in countries with strict regulation. When permanent positions are combined with strong employment protection, temporary employees risk getting stuck in insecure jobs (Barbieri, 2009).

Another factor that probably affects temporary employees' possibilities of establishing themselves on the labor market is the state of the business cycle. Holmlund and Storrie (2002) have investigated the trend for temporary employment during the 1990s, when Sweden's legislation was changed. Their conclusion is that these changes in legislation can hardly explain the development. Instead, they assert that the deep recession at the start of the 1990s was one major explanation for the sharp increase in temporary employment. They highlight the fact that the increase in temporary employments is to be found in macroeconomic changes, primarily during recessions and crises, and claim that the proportion of temporary employees falls at the beginning of a crisis and then rises. This relationship is due to the repercussions of an economic crisis reducing the number of permanent employees. As the economy is perceived to be more uncertain, companies become more likely to minimize their risk-exposure by offering temporary contracts rather than permanent employment. Due to their experiences of a recession, job seekers are also more willing to accept these types of contract. During the period that Holmlund and Storrie investigated, the increase in temporary employments applied to three categories: on-call, project, and probationary employment (Holmlund \& Storrie, 2002, p. 251). Later on, Holmlund (2009) found that the argument was strengthened when comparing with other countries. As an example, he compared Norway, which has had low unemployment and has not seen an increase in the proportion of temporary employees, with Finland, where both the level of unemployment and the proportion of temporary employments increased dramatically during the 1990 s. 
Emmenegger (2014, p. 289 ff) argues, like Homlund and Storrie, that it is not legislative changes per se that explain the increase in the number of temporary employees, but that this is a consequence of the shift in power resources due to an increased level of unemployment. On the basis of a power-resource perspective, the employees' power can increase, and terms and conditions of employment can be improved, when the supply of labor is low. When unemployment is high, the employee's negotiating position is impaired instead (Korpi, 1978, p. 130). An increase in the number of those unemployed during a recession can, using this line of reasoning, be considered to put greater pressure on the labor force to accept temporary employment.

All in all, the review shows that there has been some research into the so-called stepping-stone hypothesis. Even though these studies are based on longitudinal data, they are still limited to one cohort. Our study encompasses 19 cohorts during the period 1992-2010. This long time period means that our data cover all stages of business cycles. However, our main theoretical contribution lies in that we elaborate the understanding of the multitudinous aspects of the concept of temporary employment. International studies often deal with temporary employees as one category, which hides the fact that different types of temporary employment, for example, on-call employees, substitutes, and project employees, have different terms and conditions that can entail entirely different possibilities of transitioning from temporary employment to permanent jobs. In addition, there are no Swedish studies of how temporary employees' possibilities of transitioning into permanent jobs have changed across time.

\section{Aim and research questions}

The aim of this study is to explain the effect of temporary employment for the future labor market status. Three different kinds of explanations are tested: The employers' motives of employing on temporary contract (reflected in type of temporary contract), individual attributes, and structural factors. The overarching aim is broken down into the following research questions:

- How have different types of temporary employment developed during the period 1992-2010 on the Swedish labor, and how can the development be understood and explained?

- Which factors explain the future labor market status for temporary employees?

\section{Materials and methods}

This study is based on data from the LFS for the period 1992-2010, in which each volume consists of 2-year panels. The LFS includes detailed data on the adult population and their labor market status, among other things vis-à-vis the form of employment and the type of temporary employment. The LFS is composed of three separate monthly samples every quarter, containing approximately 20,000 individuals per sample. Each sample consists of eight different panels (rotation groups) where each individual is interviewed once a quarter, totalling eight times over a 2-year period. At each quarter, one rotation group is replaced. Our data consist of LFS participants between 1992 and 
2010, that is, a total of 19 cohorts where each cohort consists of all individuals belonging to the first rotation group each year. We then monitor those individuals over the ensuing eight quarters. This means that the individuals on the panels for a certain year have starting points spread across every month during that year. To exemplify an individual entering the LFS in January 1997 (i.e., belonging to rotation group 1) is someone we will be able to monitor until October 1998, while an individual entering in December 1997 is someone we will be able to monitor until September 1999. The advantage of this arrangement is that we obtain starting points throughout the entire year for each annual panel, thus reducing the significance of seasonal effects. In our analyses, we focus on measuring points 1 and 8 , that is, what has happened to the individuals a little less than 2 years later.

In total, our database encompasses 592,496 individuals in the age range of 16-64 years. Of these, we can monitor 453,550 for all eight measuring points. There are, however, some critical periods that reduce the sample even further. First, this applies to the end of the period, where we are unable to monitor the 2010 panel for 2 years (the last monthly panels come in during 2012). Second, this applies to cohorts 2003 and 2004, which have their last measuring point during 2005. Here, a break occurs due to rearranging the LFS, causing these panels' measuring points during 2005 to disappear. This means that the actual selection size is 429,481 individuals (which exclude panels starting in 2003, 2004, and 2010). The smallest annual selection is 24,535 individuals, while the largest is 31,403 .

In the upcoming analyses, the overall sample will be used for certain descriptive statistics. The primary aim of the analysis is, however, to study the mobility of temporary employees into permanent jobs, and other statuses on the labor market. For these analyses, 30,536 individuals will be included. The smallest and largest annual samples of temporary employees are 1617 and 2607 individuals, respectively.

The central dependent variable in the upcoming analyses is the labor market situation. Here, we differentiate between permanent employment, temporary employment, being self-employed, unemployed, and not in the labor force. In the analyses, we will thus be studying the chances of a person in temporary employment at measuring point 1 being in one of the five above-listed situations at time point 8 (just under 2 years later).

The central independent variables used in the analyses are the type of temporary employment, gender, age, education, country of birth, and normal working hours, which are all related to the risk of finding yourself in a temporary employment contract or unemployed. Of key interest is the first-mentioned independent variable. As Håkansson (2001) has shown, the type of temporary employment is an important predictor for the possibility to transit into a more stable position in the labor market. In the LFS, it is possible, over all the years being studied here, to distinguish the key forms, that is substitute, probationary employee, seasonal worker, project employee, and employees on-call. Over and above these, there is also a category called elected representative, along with a number of different categories of labor market policy measures. These categories will, however, be omitted from the upcoming analyses.

Some categories have, however, been changed or added to the LFS. This applies to 'school staff employed by the term and school year', who started being accounted for separately in the LFS in 1996. In 2005, a further two categories were added: 'Employed on an hourly-basis with an agreed rota for a specific period' and the category 'Temporary work reference week'. In 2008, the category 'General Temporary Employment 
(GTE)' also started being used. We have pooled these four categories together, calling them 'Miscellaneous Temporary Employment' in the analyses. It should be noted that the LFS is a question-based survey, entailing that it is the respondents' own classification that determines how they respond, that is, it is not the legal contract status of the temporary employment that is being measured. This is primarily noticeable when it comes to GTE, when only $1.8 \%$ of all temporary employees deem themselves to belong to that category when it is introduced in 2008.

Another key variable in the upcoming analyses is unemployment level. Here, we measure unemployment on a monthly level by means of adding monthly statistics from SCB. It is important, however, to note that unemployment is measured at the same time as the outcome variable, that is, at the eighth measuring point. The reason for this is that unemployment should be playing a greater part at the time the outcome is measured than 2 years earlier (first measuring point). As shown in Fig. 1, there has been strong growth in temporary contracts during the 1990s, while thereafter the increase in temporary contracts levels out. The proportion of temporary employment can also play a part as regards possibilities of making the transitions studied. We have thus included the proportion of temporary employees on the monthly level in the analyses. We have also added a time trend variable to the analysis $(1992$, January $=0)$ in order to study if there is a general trend as regards the possibility of different transitions.

In the article, we primarily use multilevel binomial logistic regression as a method of analysis. This means, first, that we make separate analyses for each respective transition [e.g., temporary $(\mathrm{t} 1) \rightarrow$ permanently employed $(\mathrm{t} 8)$; temporary $(\mathrm{t} 1) \rightarrow$ unemployed $(\mathrm{t} 8)$, etc.], resulting in our obtaining a dichotomous outcome variable in each respective analysis. In the case of such outcome variables, binomial logistic regressions are suitable (Long, 1997). Second, we want to take into account, via multilevel analysis, the fact that the data are clustered, since it consists of separate samples on the monthly level. If this structure is not taken into account, there will be a risk of the standard errors becoming distorted, and the standard errors for variables on a higher level (in our case, unemployment and share of temporary employed on the monthly level and the trend variable) being miscalculated due to the number of degrees of freedom being overestimated (Hox, 2002). We will thus be estimating a mixed model in which variable coefficients are calculated as fixed effects, but in which the intercept is allowed to vary between the months (random effect).

\section{Results}

Previous research has shown that the numbers of temporary contracts are related to the business cycle (Holmlund \& Storrie, 2002). This may indicate that the probability to transfer from temporary to permanent employment varies due to the unemployment rate. We therefore start our analysis with a description of the trend for temporary employment as a proportion of all employments from the end of the 1980s up to today. Figure 1 shows three graphs of the monthly trend of temporary employment, and an additional graph of the unemployment level. First, it is Statistic Sweden's (SCB) monthly statistics of temporary employment (grey line), which shows a clearly jagged pattern of the seasonal variations, generally indicating an increase in temporary contracts during the summer months (Jun-Aug). In simple terms, many young people and 
Figure I: Proportion (\%) of temporary employees among all employees, and the unemployment level. Monthly (temporary) and seasonally adjusted (temporary and unemployment) official statistics (Statistics Sweden), as well as panel data concerning the proportion of temporary for first rotation group per month and year.

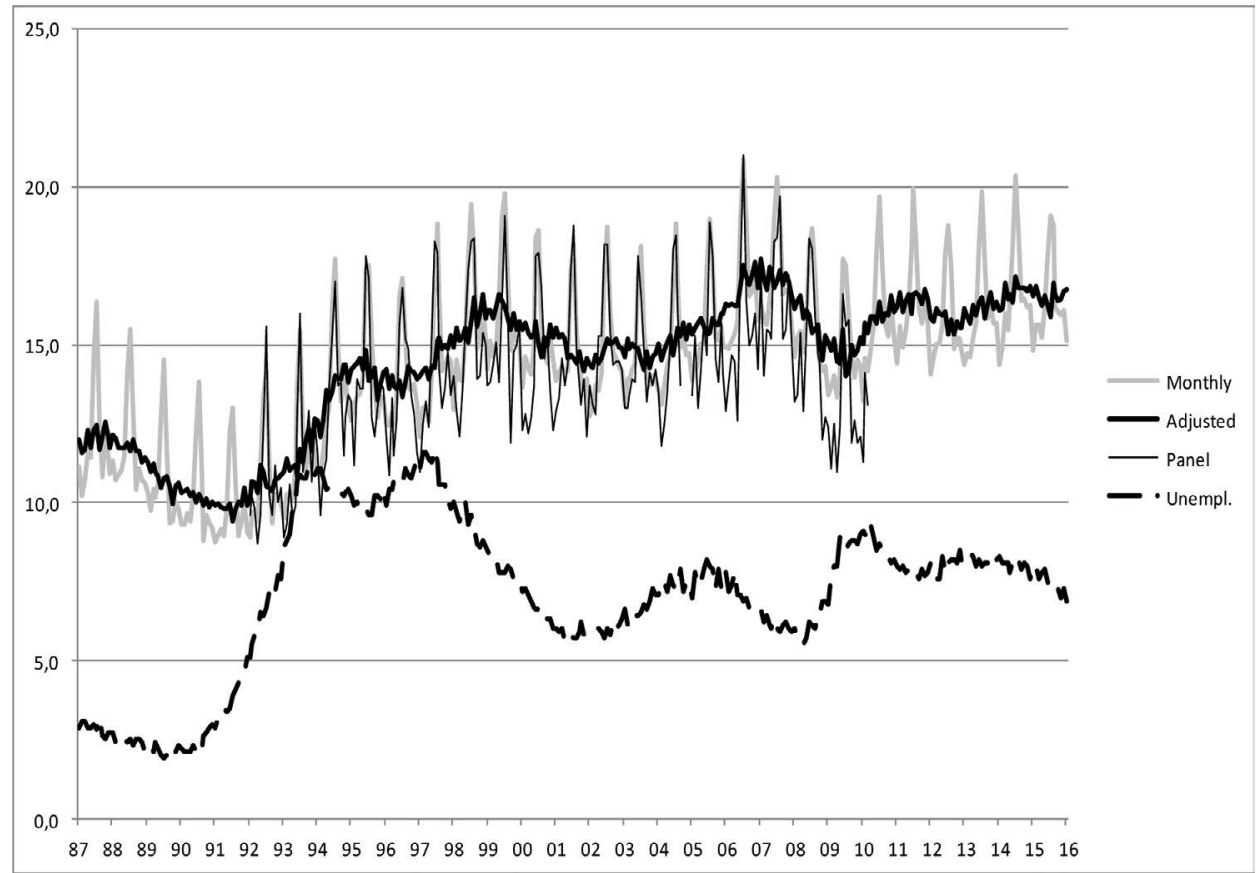

students get holiday jobs at the start of the summer, jobs which then end when term time comes around.

In order to more clearly be able to discern trends in the proportion of temporary employments, Statistic Sweden also calculates so-called seasonally adjusted figures (thicker black line). This shows that there was a trend break in the use of temporary contracts during the 1990s. When it comes to the level of the proportion of temporary employments, we can distinguish several time periods in the diagram. Up until 1992, the proportion of temporary contracts was on a relatively low level of around $11 \%$. The following year, the proportion starts to rise relatively constantly, reaching $14.1 \%$ in 1995. After that, the increase stops for a couple of years and then starts rising again from $14.6 \%$ in 1997 to $16.0 \%$ in 1999 . Post- 2000 , the increase in temporary contracts levels out, but on a considerably higher level, in relative terms, than before the crisis in the 1990s. A new peak is reached year 2007, just prior to the financial crisis, when the proportion on average was $17.1 \%$ (in July 2006, however, $20.9 \%$ temporary was measured, which is the largest proportion for a single month during the entire period). During the years of the financial and Euro crises, the proportion of temporary contracts falls considerably, and subsequently rises again.

The thinner black curve shows the proportion of temporary employees based on the data used in this article. In the diagram, the panel itself is not used, but only the 
employment status of the first rotation group every month and per year. We have data from January 1992 until March 2010 (the dashed vertical lines). It should be observed that these data are, in principle, the same as Statistic Sweden's official monthly statistics, the difference being that Statistic Sweden does its calculations on the basis of all eight rotation groups per month, while we only use the first rotation group. Thus, our selection per month is both less and encumbered with a slightly greater level of uncertainty. If we compare the curves (month and panel), they correspond quite well. During 2009, however, there are several monthly discrepancies over $2 \%$. If we count the annual means on our monthly figures, they correspond well with the official statistics. We are thus able to establish that our data have a high level of validity.

To the diagram, we have also added the seasonally adjusted unemployment on the monthly level. Here, the crisis of the 1990s and the financial crisis are clearly visible. There is also a minor peak in unemployment during the mid-2000s. If we compare the seasonally adjusted graphs for unemployment with the proportion of temporary employment, we will be able to discern different patterns. The increase in the proportion of temporary contracts during the 1990s starts a while after rising levels of unemployment and, when unemployment falls in the mid-1990s, the proportion of temporary contracts continues to increase. During the financial crisis of 2008-2009, the proportion falls while unemployment simultaneously rises, which is a reversed pattern compared to the experiences of the 1990s. And, during the final years of the time series, the proportion of temporary employees rises despite falling unemployment.

Table I Correlations between unemployment (I month) and the proportion of temporary employees

\begin{tabular}{ccccccc}
\hline & $1987-2016$ & $1987-1990$ & $1991-1999$ & $2000-2007$ & $2008-2010$ & $2011-2016$ \\
\hline Level & $0.436^{* * *}$ & $0.416^{* *}$ & $0.529 * * *$ & $0.271 * *$ & 0.152 & 0.182 \\
\hline
\end{tabular}

*** $\mathrm{p}<0.01$ **** $\mathrm{p}<0.001$.

We correlate the nonseasonally adjusted (month) unemployment level and the proportion of temporary contracts (Table 1). We use the unemployment level for the month prior to the monthly figure for temporary employees, as this has generally shown itself to have the strongest relationship in comparison with contemporary figures or 2 months' lag. For the entire period of January 1987 to January 2016, the correlation is 0.436 , that is, a higher level of unemployment is accompanied by a higher proportion of temporary employment. We have also calculated correlations for five different periods on the basis of how unemployment has grown. The first period occurs prior to the unemployment crisis of the 1990s. Here, there is a rather strong relationship between unemployment level and the proportion of temporary jobs. This connection is reinforced slightly during the crisis of the 1990s. After that, we can see a positive but considerably weaker relationship compared with the 1990s. During the financial crisis, and the ensuing period, it weakens further and is no longer significant. This indicates that the rise in temporary contracts, following the financial crisis, cannot be related in any simple way to the level of unemployment.

So far, we have treated employees with temporary employment as one single category. However, there is a considerable heterogeneity within this category concerning the kind of temporary employment. Table 2 summarizes the principal forms measured in the 
Table 2 Types of temporary employment between 1992 and 2009

\begin{tabular}{|c|c|c|c|c|c|c|c|c|c|}
\hline & Substiute & $\begin{array}{c}\text { Probationary } \\
\text { employee }\end{array}$ & $\begin{array}{l}\text { Intern- } \\
\text { ship }\end{array}$ & $\begin{array}{c}\text { Summer } \\
\text { work }\end{array}$ & $\begin{array}{l}\text { Seasonal } \\
\text { employee }\end{array}$ & $\begin{array}{c}\text { Project } \\
\text { employee }\end{array}$ & $\begin{array}{l}\text { On- } \\
\text { call }\end{array}$ & $\begin{array}{c}\text { Miscel- } \\
\text { laneous } \\
\text { temporary }\end{array}$ & Total \\
\hline 1992 & 50.0 & 4.6 & 1.6 & 7.6 & 5.5 & 13.8 & 12.6 & 4.3 & 100 \\
\hline 1993 & 46.1 & 4.2 & 2.5 & 6.8 & 6.2 & 15.1 & 15.2 & 3.7 & 100 \\
\hline 1994 & 41.4 & 6.3 & 1.1 & 8.2 & 5.4 & 19.4 & 16.4 & 1.7 & 100 \\
\hline 1995 & 40.0 & 8.7 & 1.8 & 8.4 & 5.2 & 18.8 & 15.4 & 1.7 & 100 \\
\hline 1996 & 38.0 & 6.8 & 1.4 & 8.5 & 4.0 & 19.2 & 19.1 & 3.1 & 100 \\
\hline 1997 & 34.6 & 6.0 & 2.0 & 7.5 & 5.0 & 20.8 & 20.6 & 3.5 & 100 \\
\hline 1998 & 35.7 & 7.8 & 1.5 & 7.6 & 4.2 & 20.4 & 18.6 & 4.1 & 100 \\
\hline 1999 & 35.5 & 9.6 & 1.0 & 6.8 & 5.1 & 18.0 & 18.1 & 6.1 & 100 \\
\hline 2000 & 34.1 & 11.7 & 1.5 & 6.3 & 5.4 & 17.9 & 18.3 & 4.8 & 100 \\
\hline 2001 & 33.1 & 10.1 & 1.2 & 8.3 & 5.1 & 17.3 & 19.9 & 4.9 & 100 \\
\hline 2002 & 34.1 & 9.1 & 1.3 & 7.0 & 5.7 & 16.4 & 20.8 & 5.5 & 100 \\
\hline 2003 & 35.3 & 8.9 & 0.7 & 6.8 & 5.7 & 17.3 & 21.5 & 3.9 & 100 \\
\hline 2004* & 32.3 & 7.8 & 1.2 & 8.9 & 7.1 & 16.5 & 22.4 & 3.8 & 100 \\
\hline 2005 & 28.3 & 7.8 & 1.3 & 6.7 & 4.3 & 14.8 & 21.1 & 15.7 & 100 \\
\hline 2006 & 28.1 & 10.1 & 1.2 & 5.3 & 5.5 & 13.0 & 17.7 & 19.1 & 100 \\
\hline 2007 & 24.9 & 11.5 & 0.9 & 6.0 & 4.2 & 13.9 & 18.1 & 20.5 & 100 \\
\hline 2008 & 23.2 & 11.3 & 1.0 & 5.7 & 5.3 & 11.1 & 18.2 & 24.2 & 100 \\
\hline 2009 & 23.1 & 8.0 & 1.1 & 4.6 & 4.9 & 11.7 & 20.6 & 26.1 & 100 \\
\hline Mean & 33.6 & 8.6 & 1.4 & 6.9 & 5.0 & 16.2 & 18.3 & 9.9 & 100 \\
\hline
\end{tabular}

Share of all temporary employment. Percent. $N=37,081$.

*Due to the reorganization of LFS in 2005, 2004 contains monthly measuring points up until September, but the last quarter is missing.

LFS, as well as some merging that had to be done for pragmatic reasons (see Materials and methods section). Here, only data from our database are used, and it is the outcome of the first rotation group every year that is shown.

The table indicates changes as regards the distribution of different types of temporary contracts. Substitutes have gradually fallen in their relative proportion of all temporary employment, from having been the clearly dominant form, with around half of all temporary employed in 1992, to just under a quarter in 2008. Even though the substitutes' relative share of temporary employments has fallen, it can still be worth noting that substitutes constituted approximately 5\% of all employees between 1992 and 2004, explained by the fact that the overall share temporary employment during the same period had risen from approximately $10 \%$ of all employees to $15 \%$ (see Fig. 1 ). On-call employees have clearly increased in proportion during the period; the strongest increase takes place during the 1990 s when it approached $20 \%$ of all temporary employed. Project jobs show a pattern of their own with a strong increase during the 
1990s, followed by a strong reduction during the 2000s. We also have a category that has increased considerably during the latter part of the period and this is the one we have chosen to call 'Miscellaneous Temporary'. Since 2005, there has been a type of temporary employment in this category called 'Employed on an hourly-basis with an agreed rota for a specific period'. This group includes those working on an hourly basis, comparable to on-call employees. One difference vis-à-vis on-call employees is, however, that they work with some form of rota as a basis. How this group was previously classified is difficult to exactly ascertain, but this group was probably distributed among several of the earlier categories. In terms of numbers, all types of temporary employments fall during the 2008-2009 crisis. However, among the temporary employments, the share of on-call employees and miscellaneous temporary employments increases, which means that a good $45 \%$ of all temporary employees are either on-call or hourly-waged in 2009.

If we look at what distinguishes the categories on-call and miscellaneous temporary employees, these employees are young (16-24) - just over $49 \%$ and $40 \%$, respectively, belong to the categories, compared with approx. $31 \%$ of the substitutes - and working part time at less than 30 hours a week $(73 \%$ and $48 \%$, respectively, compared with $25 \%$ of the substitutes). As regards educational level, it is higher among miscellaneous temporary employees than among on-call employees, with $35.7 \%$ having a university education compared with $23.8 \%$ of the on-call employees and $33.5 \%$ of the substitutes. When it comes to country of birth, the categories do not differ appreciably - among the substitutes, there are slightly more people who have Swedish origins.

The next stage of the analysis is to utilize the panel in the database and to study the probability of different transitions, given that someone is in temporary employment at the point of departure. We differentiate between five different labor market situations as the outcome variable: temporary employee, permanent employee, unemployed person, self-employed person, or someone who is not a member of the labor force.

Figure 2 shows the mobility of temporary employees. At the point of departure, measuring point $1,100 \%$ is temporary employed. This proportion falls on each occasion of measuring. At measuring point 5 , just under $50 \%$ is temporary employed and, at the final measuring point, the proportion is approximately $35 \%$. At the same time, the share of permanent employment rises with time. At the final measuring point, almost $38 \%$ are permanent employed. The fact that a rather large proportion of the temporary employees at time-point 1 are in permanent employment after almost 2 years lends some support to the stepping-stone hypothesis. At the same time, we have to emphasize that over $60 \%$ of these are still in a rather uncertain labor market situation (temporary employment, unemployed, self-employed, not a member of the labor force) at time-point 8 . In the following analyses, we shall focus on the factors capable of explaining this outcome.

Table 3 summarizes a series of binomial logistic regressions for temporary employees at time-point 1 finding themselves in different labor market situations at time-point 8 . What is presented here is the odds ratios of different categories finding themselves in another labor market situation (permanent employment contracts; self-employed; unemployed; not a member of the labor force), compared with remaining in temporary employment. The independent variables originate from measuring occasion 1 , where it is primarily the type of temporary employment that is of key interest. However, two of the variables, unemployment level and proportion of temporary employees, refer to the monthly level at measuring point 8 . Thus, we are not studying the long-term effects of 
Figure 2: Temporary employees at time-point I and their labor market status for the seven following quarters. Percent. Data for 1992-2009. N Max $(I)=30,253, \mathrm{~N} \min (8)=28,809$.

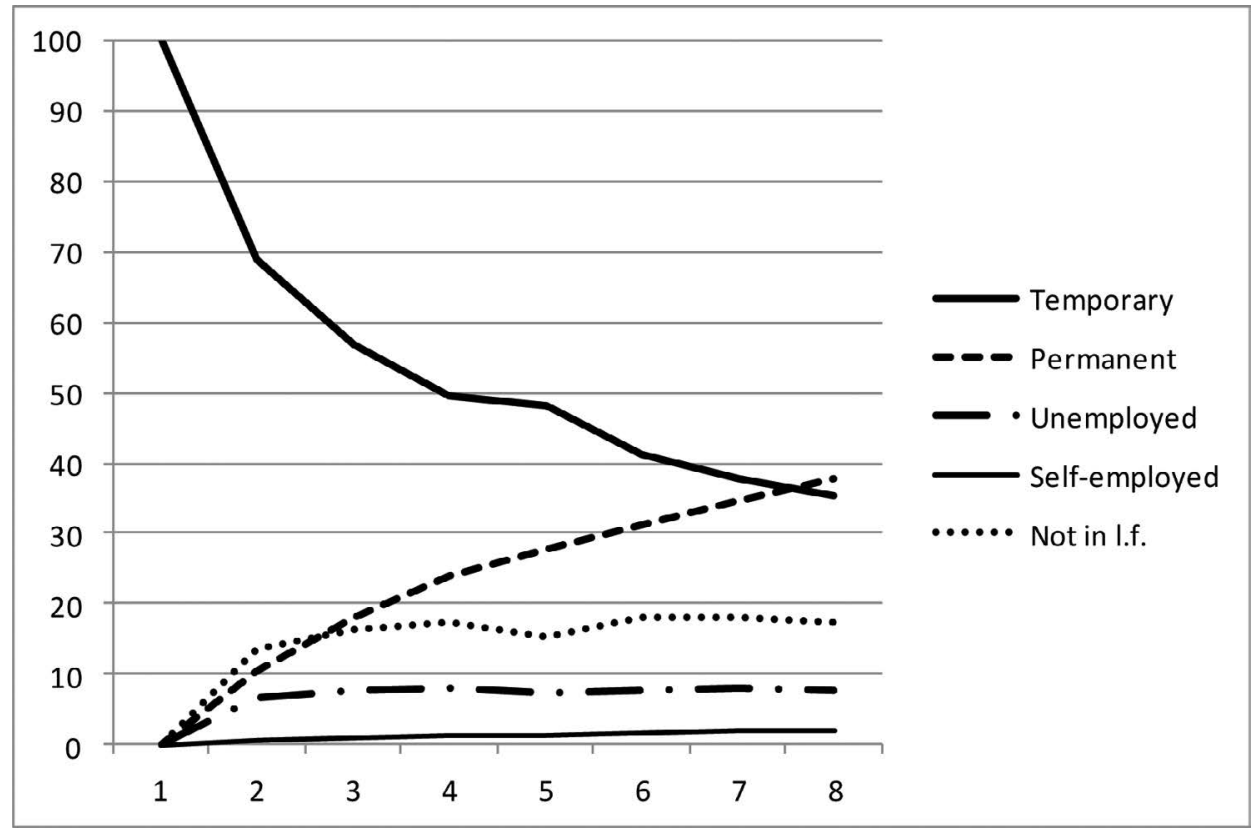

these variables; instead, they are contemporary with the outcome variable. The analysis also contains a time trend variable (monthly level at measuring occasion 1).

If we focus on the key independent variable - type of temporary employment at measuring point 1 - we will firstly be able to see that, in comparison with substitutes (reference category), several of the other forms have a lower odds of transitioning, at measuring point 8 , into permanent employment. This primarily not only applies to seasonal work but also to employees of the types on-call, project, holiday, and miscellaneous temporary. For example, the odds of on-call employees finding themselves in permanent employment after 2 years are approximately half as great $(0.52)$ as for substitutes. There is, however, a category with significantly higher odds than substitutes of finding themselves in permanent employment, and this is probationary employees, whose odds are more than twice as great.

If we instead look at the risk of ending up unemployed at measuring point 8 , we will be able to point out, apparently paradoxically, that probationary employees also run a risk of being unemployed that is almost twice as great as those employed as substitutes. At the same time, this state of affairs is in the nature of probationary employment: After 6 months, probationary employment must transition into either permanent employment or dismissal. We are thus seeing the effect of the employer's 'screening' of the probationary employee at this measuring point. Additionally, those with an internship run a greater risk than substitutes of being unemployed 2 years later. However, this risk is not balanced by a greater chance of gaining permanent employment. As regards, 
Table 3 Labor market transitions for temporary employees after slightly less than 2 years (measuring points I and 8)

\begin{tabular}{|c|c|c|c|c|c|c|c|c|}
\hline & \multicolumn{2}{|c|}{$\begin{array}{c}\text { From } \\
\text { temporary to } \\
\text { permanent }\end{array}$} & \multicolumn{2}{|c|}{$\begin{array}{c}\text { From } \\
\text { temporary to } \\
\text { unemployed } \\
\end{array}$} & \multicolumn{2}{|c|}{$\begin{array}{l}\text { From tempo- } \\
\text { rary to self- } \\
\text { employed }\end{array}$} & \multicolumn{2}{|c|}{$\begin{array}{l}\text { From tempo- } \\
\text { rary to not in } \\
\text { labor force }\end{array}$} \\
\hline & $b$ & $\begin{array}{l}\text { Odds } \\
\text { ratio }\end{array}$ & $b$ & $\begin{array}{l}\text { Odds } \\
\text { ratio }\end{array}$ & $\mathrm{b}$ & $\begin{array}{l}\text { Odds } \\
\text { ratio }\end{array}$ & $\mathrm{b}$ & \\
\hline $\begin{array}{l}\text { Type of temporary } \\
\text { (ref: Substitute) } \\
\text { On-call employee } \\
\text { Miscellaneous temporary } \\
\text { Project employee } \\
\text { Seasonal employee } \\
\text { Summer work } \\
\text { Internship } \\
\text { Probationary employee } \\
\end{array}$ & $\begin{array}{c}-0.653^{*} * * \\
-0.540 * * * * \\
-0.448 * * * \\
-0.965 * * * \\
-0.716^{*} * * \\
0.032 \\
0.877 \text { **** }\end{array}$ & $\begin{array}{l}0.520 \\
0.583 \\
0.639 \\
0.381 \\
0.489 \\
1.033 \\
2.404 \\
\end{array}$ & $\begin{array}{l}-0.193^{*} \\
-0.189 \\
0.204^{*} \\
0.172 \\
0.114 \\
0.627 * * \\
0.691^{*} * * \\
\end{array}$ & $\begin{array}{l}0.825 \\
0.828 \\
1.227 \\
1.188 \\
1.121 \\
1.872 \\
1.996 \\
\end{array}$ & $\begin{array}{l}0.051 \\
-0.070 \\
0.236 * \\
0.142 \\
-0.023 \\
0.146 \\
0.677 * * * \\
\end{array}$ & $\begin{array}{l}1.052 \\
0.933 \\
1.266 \\
1.153 \\
0.978 \\
1.157 \\
1.967 \\
\end{array}$ & $\begin{array}{c}-0.009 \\
-0.09 \mid \\
-0.001 \\
0.028 \\
0.790 * * * \\
0.751 * * * * \\
0.445^{*} * * \\
\end{array}$ & $\begin{array}{l}1.009 \\
0.913 \\
0.999 \\
1.028 \\
2.203 \\
2.119 \\
1.561\end{array}$ \\
\hline $\begin{array}{l}\text { Gender (ref:Woman) } \\
\text { Man }\end{array}$ & $0.165 * * * *$ & 1.179 & $0.423 * * * *$ & 1.526 & $.538 * * *$ & 1.713 & -0.059 & 0.943 \\
\hline $\begin{array}{l}\text { Age (ref 60-64) } \\
16-19 \\
20-24 \\
25-29 \\
30-34 \\
35-39 \\
40-44 \\
45-49 \\
50-54 \\
55-59 \\
\end{array}$ & $\begin{array}{l}0.160 \\
0.417 * * * * \\
0.583 * * * \\
0.630 * * * \\
0.573 * * * \\
0.559 * * * \\
0.423 * * \\
0.370 * * \\
0.288\end{array}$ & $\begin{array}{l}1.174 \\
1.517 \\
1.791 \\
1.878 \\
1.774 \\
1.748 \\
1.526 \\
1.448 \\
1.334\end{array}$ & $\begin{array}{l}-0.551 \text { **** } \\
-0.555^{* * * *} \\
-0.329 * \\
-0.133 \\
-0.210 \\
-0.204 \\
-0.148 \\
0.003 \\
-0.045 \\
\end{array}$ & $\begin{array}{l}0.577 \\
0.574 \\
0.720 \\
0.875 \\
0.811 \\
0.815 \\
0.862 \\
1.003 \\
0.956 \\
\end{array}$ & $\begin{array}{l}-0.603 * * \\
-0.628 * * \\
-0.220 \\
-0.177 \\
-0.022 \\
-0.087 \\
-0.115 \\
-0.126 \\
-0.419\end{array}$ & $\begin{array}{l}0.547 \\
0.534 \\
0.802 \\
0.838 \\
0.979 \\
0.916 \\
0.891 \\
0.881 \\
0.657 \\
\end{array}$ & $\begin{array}{l}-0.47 \mid \text { **** } \\
-0.590 * * * * \\
-0.934 * * * \\
-1.068 * * * \\
-1.41 \mid * * * \\
-1.625 * * * \\
-1.819 * * * \\
-1.81 \mid * * * \\
-1.325 * * *\end{array}$ & $\begin{array}{l}0.624 \\
0.554 \\
0.393 \\
0.344 \\
0.244 \\
0.197 \\
0.162 \\
0.163 \\
0.266\end{array}$ \\
\hline $\begin{array}{l}\text { (ref Sweden) } \\
\text { Nordic countries } \\
\text { Europe } \\
\text { Rest of the world } \\
\end{array}$ & $\begin{array}{r}0.038 \\
-0.026 \\
-0.130 * \\
\end{array}$ & $\begin{array}{l}1.038 \\
0.979 \\
0.878\end{array}$ & $\begin{array}{l}0.084 \\
0.416^{*} * \\
0.582 * * * * \\
\end{array}$ & $\begin{array}{l}1.088 \\
1.516 \\
1.789 \\
\end{array}$ & $\begin{array}{l}-0.040 \\
-0.188 \\
-0.000 \\
\end{array}$ & $\begin{array}{l}0.961 \\
0.829 \\
1.000 \\
\end{array}$ & $\begin{array}{l}0.194 \\
0.234 * \\
0.263^{* * *} \\
\end{array}$ & $\begin{array}{l}1.214 \\
1.264 \\
1.301 \\
\end{array}$ \\
\hline $\begin{array}{l}\text { Education (refTertiary) } \\
\text { Primary } \\
\text { Secondary } \\
\end{array}$ & $\begin{array}{l}-0.174 * * \\
-0.071 \\
\end{array}$ & $\begin{array}{l}0.840 \\
0.932 \\
\end{array}$ & ********* & $\begin{array}{l}1.637 \\
1.668 \\
\end{array}$ & $\begin{array}{r}-0.6 \\
0 .\end{array}$ & & $\begin{array}{l}0.2 \\
0.1 \\
\end{array}$ & $\begin{array}{l}1.239 \\
1.159 \\
\end{array}$ \\
\hline $\begin{array}{l}\text { Working hours/week } \\
\text { (ref: } 35-40 \text { ) } \\
\text { I-19 } \\
20-29 \\
30-34 \\
41+ \\
\end{array}$ & $\begin{array}{l}-0.515 * * * * \\
-0.304 * * * * \\
-0.152 * * \\
-0.166 * \\
\end{array}$ & $\begin{array}{l}0.598 \\
0.738 \\
0.859 \\
0.847 \\
\end{array}$ & $\begin{array}{l}-0.201^{*} \\
-0.100 \\
-0.173^{*} \\
-0.275 \\
\end{array}$ & $\begin{array}{l}0.818 \\
0.905 \\
0.841 \\
0.759 \\
\end{array}$ & $\begin{array}{l}0.112 \\
0.143 \\
0.082 \\
0.153 \\
\end{array}$ & $\begin{array}{l}1.118 \\
1.154 \\
1.085 \\
1.166 \\
\end{array}$ & $\begin{array}{l}0.159 * * \\
-0.051 \\
-0.056 \\
-0.145 \\
\end{array}$ & $\begin{array}{l}1.173 \\
0.951 \\
0.946 \\
0.865 \\
\end{array}$ \\
\hline $\begin{array}{l}\text { Sector (ref: Privat } \\
\text { Public }\end{array}$ & $-0.489 * * *$ & 0.613 & $-0.309 * * * *$ & 0.734 & -0.636 **** & 0.530 & $-0.132 * *$ & 0.876 \\
\hline $\begin{array}{l}\text { SEI (ref: Upper white-collar) } \\
\text { Unqualified blue-collar } \\
\text { Qualified blue-collar } \\
\text { Lower white-collar } \\
\text { Intermediated white-collar }\end{array}$ & $\begin{array}{l}0.087 \\
0.139 * \\
0.214^{*} * \\
0.262^{* * *} \\
\end{array}$ & $\begin{array}{l}1.091 \\
1.149 \\
1.238 \\
1.300 \\
\end{array}$ & $\begin{array}{l}0.692 * * * \\
0.575 * * * * \\
0.711 * * * * \\
0.561 * * * * \\
\end{array}$ & $\begin{array}{l}1.998 \\
1.777 \\
2.035 \\
1.752 \\
\end{array}$ & $\begin{array}{r}-0.248 \\
-0.113 \\
-0.137 \\
0.119 \\
\end{array}$ & $\begin{array}{l}0.780 \\
0.893 \\
0.872 \\
1.127 \\
\end{array}$ & $\begin{array}{l}0.672 * * * * \\
0.522 * * * * \\
0.716 * * * \\
0.678 * * * \\
\end{array}$ & $\begin{array}{l}1.957 \\
1.685 \\
2.047 \\
1.971 \\
\end{array}$ \\
\hline Level of unemployment & $-0.092 * * * *$ & 0.912 & $0.158 * * * *$ & 1.172 & 0.041 & 1.042 & $-0.035^{*}$ & 0.966 \\
\hline $\begin{array}{l}\text { Proportion temp. } \\
\text { employed }\end{array}$ & $-0.039 * * * *$ & 0.962 & $-\left.0.04\right|^{* * *}$ & 0.960 & -0.026 & 0.974 & -0.114 ******* & 0.892 \\
\hline Time trend & $0.001 * *$ & 1.001 & $0.004 * * * *$ & 1.004 & 0.001 & 1.001 & $-0.00 \mid$ 米* & 0.999 \\
\hline Intercept & 1.313 ***** & 3.717 & -3.359 ****** & 0.035 & $-2.513 * * * *$ & 0.081 & 1.474 & 4.365 \\
\hline Varians Intercept & $0.020 *$ & & 0.013 & & 0.000 & & 0.026* & \\
\hline $\mathbf{N}$ & 20,27 & & 11,918 & & 10,363 & & 14,70 & \\
\hline
\end{tabular}

Levels of significance: ${ }^{*} \mathrm{p}<0.05$; ** $\mathrm{p}<0.01$; ${ }^{* * * *} \mathrm{p}<0.00$ I.

Logistic regression coefficients and odds ratios. Multilevel binomial regressions (separate analyses). 
on-call employees, and miscellaneous temporary employees, the probability of being unemployed is on a slightly lower level than for substitutes - in the former case, the difference is significant. For project employees, the risk is slightly higher instead.

In the table, transitions into two other forms are also distinguishable, that is, being either self-employed or no longer a member of the labor force. Probationary and project employees have a greater odds of becoming self-employed at measuring point 8 than do substitutes. And, as regards the risk of leaving the labor force, this primarily applies to trainees, holiday workers, and probationary employees.

Concerning the control variables, a number of things can be noted. Age is an important factor for two transitions - that is, to permanent employment and to a position outside the labor force. The relationship looks as if it is shaped like an upside-down $U$ as regards transitions into permanent employment. The chances of the youngest (16-19) are on about the same level as those of the eldest (60-64), then increasing up to and including the 30-34 year olds, who have the greatest odds of transitioning into permanent employment. After that, the odds decrease. Concerning transitions into a position outside the labor force, the odds decrease right up to the oldest age category (reference category), which clearly has the greatest probability of leaving the labor force. One plausible explanation here is retirement in the eldest. For transitions from temporary employment into unemployment and self-employment, the two youngest categories have a lower level of probability than the other age categories. When it comes to gender, men have a slightly higher probability of experiencing all transitions than do women, besides leaving the labor force, where there is no significant difference. Above all, men have a greater probability than women of moving from a temporary contract to self-employment.

Country of birth plays a part in three of the transitions. Those born in Europe or the rest of the world have a larger odds than Swedish-born people of transitioning into unemployment or leaving the labor force. Above all, this applies to those born outside Europe. For the last-mentioned category, we also find a slightly lower odds of transitioning into permanent employment. Those with just primary education, in comparison with those with tertiary education, have a lower probability of becoming permanently employed and a greater probability of transitioning into unemployment, or leaving the labor force. The two last-mentioned transitions also apply to those with secondary education. Working hours display a special pattern. First, we can establish that those working part time have a lower odds of becoming permanently employed after 2 years than those working full time (35-40 hours). On the other hand, those with shorter working hours also have a lower odds of becoming unemployed than those working full time.

The sector in which people are employed is also of significance: Public sector employees have a lower odds than private sector employees of being in permanent employment at time-point 8 ; however, at the same time, they have a lower odds of being unemployed, self-employed, or outside the labor force after slightly less than 2 years. The findings would suggest a quite stable labor market status for temporary employees in the public sector. When it comes to socioeconomic status (SEI), we find rather complicated outcomes. Upper white-collar workers have an approximately similar probability of transitioning into permanent employment as unqualified workers. The greatest odds are instead to be found among white-collar workers on the intermediate level. On the other hand, the white-collar workers on a more senior level have a considerably lower risk of being unemployed or outside the labor force after almost 2 years than do all the other categories.

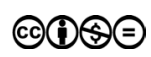


The analysis also contains structural factors measured as three continuous variables. One of these measures the unemployment level on the monthly level at measuring occasion 8 throughout the period 1992-2009. It is significantly negatively related to transitioning into permanent employment or leaving the labor force, and positively related to transitions into unemployment, where the strongest relationship applies to the last-mentioned, that is, the higher the unemployment level - the greater the risk of temporary employed to transitioning into unemployment. The second structural variable applies to the proportion of temporary employment among all types of employments (also on the monthly level). Here, we find that the greater the proportion of temporary employment - the lower the probability of undergoing all transitions (not significant with regard to being self-employed). These findings can be interpreted such that, with a growing proportion of temporary employments, the probability of remaining in such employment rises.

Finally, we have also added a time trend to the analysis. Here, we can see that, over time (and when controlling for unemployment and the proportion of temporary employment along with other variables), there are three significant tendencies: The probability of temporary employees becoming permanent employees increases with time but so, too, does the probability of becoming unemployed, all things being equal. On the other hand, the trend is negative as regards leaving the labor force; that is, over time, the odds of transitioning from temporary employment into leaving the labor force decrease.

\section{Discussion and conclusions}

\section{The trend for temporary employment}

In order to understand the effect of a temporary employment, we need to look at the overall development of temporary contracts on the labor market. Previous research suggests an association between the proportion of temporary contracts and business cycles.

The crisis of the 1990s brought with it a major change in the use of temporary contracts on the Swedish labor market. Holmlund and Storrie's (2002) conclusion, following their analysis of the 1990s crisis, is that the proportion of temporary contracts normally falls at the start of an economic crisis and then increases during an upturn. In this article, we are able to shed light on the long-term development. If we compare the trend during the 1990s with the crisis 2008-2009, the same conclusion is not that clearcut. Initially, we also find a decline in the proportion of temporary employees. However, this decline was clearly less and starting out from a significantly higher level compared with the 1990s crisis. Furthermore, the correlation between unemployment and the share temporarily employed is much weaker compared to the former crisis. These findings indicate that the 1990 s crisis was special in the sense that it entailed a shift toward a constantly high use, in relative terms, of temporary contracts on the Swedish labor market. We argue that this indicates a general change whereby employers were hiring to a greater degree via temporary contracts, regardless of the state of the business cycle. This trend was facilitated by the liberalization of the Employment Protection Act for temporary employment, starting in the early 1990s.

Auspurg and Gundert (2015) show that the willingness to accept temporary employment is contingent upon a person's negotiating strength vis-à-vis the employer. Higher 
qualification, higher SEI, and better economic resources reduce the probability of an individual accepting temporary employment, while the unemployed and those with low qualifications to a greater extent tend to accept temporary employment. In line with the results of Aupurg and Gundert, we argue that the explanation for the high numbers of temporary employees is the relatively high unemployment levels in the Swedish labor market since the 1990s. This have weakened the negotiating position of the employee vis-à-vis the employer. Thus, the employers tend to offer temporary contracts to achieve numerical flexibility, and the employees tend to accept these contracts. This can be interpreted in accordance with Holmlund's (2009) analysis of a changed balance of power in the labor market. Furthermore, another sign of a tipped power balance is the change of the relative distribution of different types of temporary employment, where substitutes a more stable form of temporary employment - are reduced trend-wise, while the most uncertain types - on-call employees and miscellaneous temporary employees - increase. Consequently, employers seem to prefer contracts offering them greater flexibility. This is in accordance with results from Gash (2008) and Houseman (2001) who point at temporary employment as a way of creating numeric flexibility in institutional contexts with strong protection of regular employment.

A high proportion of temporary contracts per se can also entail these being normalized (primarily among certain groups) that increase the acceptance of taking this type of employment. The consequence of such a 'normalisation process' makes the variation in the proportion of temporary contracts less contingent upon the status of the business cycle. How the increase of contracts aiming to provide flexibility for the employer and how the 'normalisation' of temporary contracts relate to the individual's opportunity to transit from a temporary contract to a permanent one will be discussed further in the next section.

\section{Which factors explain temporary employees' future labour market situation?}

In this article, we study the temporary employee's labor market situation after slightly less than 2 years. We compare the probability of still being in temporary employment with the probability of being permanently employed, unemployed, self-employed, and outside the labor force. In this article, three different types of explanations are tested employer motives and individual attributes such as gender, age and education, as well as structural factors.

When it comes to employer motives, our most important independent variable is the specific type of temporary employment. The analysis shows that substitutes have higher odds of gaining permanent jobs than all other types, besides probationary employees. Probationary employees having greater odds are not particularly surprising; the intention behind probationary positions is the transitions into permanent ones and they are thus the clearest example of screening - the employer wants to test the person before he/ she is employed. Concerning substitutes, it is not plausible to regard this type of contract as a way to achieve flexibility. Rather, a substitute's function is to replace somebody and thereby achieve organizational stability. Besides filling vacancies, substitutes can also function in a similar way as screening, something which can explain the fact that substitutes have a greater odds of gaining permanent employment than, for instance, project employees. This finding was also made by Håkansson (2001) in her study of a cohort 
of temporary employees in the 1990s. Also, internship could be interpreted as serving the purpose of screening. Trainees do not differ from substitutes when it comes to the probability of being permanently employed after slightly less than 2 years. On the other hand, they run almost double the risk of becoming unemployed.

On-call employment, hourly-waged employment with a rota, and seasonal employment probably reflect the employer's uncertainty regarding staffing needs and ad hoc solutions, thus responding to a need for flexibility in staffing. Two of these types, on-call and seasonal employees, have significantly lower odds of being permanent employed 2 years later. At the same time, on-call employees and other temporary employees also have lower odds of being unemployed than do substitutes.

Thus, using employer motives as an explanation only partly can explain the outcomes. The screening motive (Gash, 2008) is self-evident for probationary employees, but substitutes also seem to have this function to some extent. These forms of temporary employment also have the highest probability to lead to permanent jobs, that is, work as a stepping-stone. However, our analysis shows that temporary jobs which serve the purpose of creating flexibility for the employer provide only minor opportunities for transitions into permanent employment (cf. Barbieri, 2009, and Kalleberg, 2003). In summary, we can establish that the stepping-stone hypothesis applies to the types of temporary employment which, for the employer, work as screening, but not for the types aimed at providing the employer with flexibility. It is, in other words, essential to differentiate between types of temporary employment in any analysis of the future labor market situation. This has also been emphasized in some previous studies (Berton, 2011; Booth, 2002; Håkansson, 2001).

When it comes to individual attributes, gender, age, and education, all show significant differences as regards possibilities of becoming a permanent employee after slightly less than 2 years. Previous research has been conducted in different institutional contexts, which partly explains the nonexistence of any clear findings in these respects. Our findings differ, for example, from a Norwegian study that did not show any differences due to gender, age, and education (Neergaard, 2016).

One explanation to the nonconclusive results from previous research of individuals' probability to transfer to permanent employment is that these studies are done in varying institutional settings and different business cycles. In order to control for some aspects of a changing context across time, we control for the proportion of temporary employees and the level of unemployment during the studied period. The first variable shows that the higher the proportion of temporary employed among the employees, the greater the probability of individuals to remain in temporary employment. The result indicates that a high level of temporary employment risk to make this form of employment 'normalised', and increasing the difficulty to transit into a permanent job. Our results can be interpreted in line with analyses of Barbieri (2009) and Thelen (2014, p. 188) stating that strong employment protection for regular employees combined with lax protection for temporary employees risk a dualization of the labor market. We argue that the 'normalization' of temporary contracts is contributing to the low transition rate in Sweden, but this is only part of the explanation.

The unemployment level is of significance to all outcomes. The connection between the status of the business cycle and transitioning into a permanent job is negative, that is, with a lower level of unemployment, the probability of gaining permanent employment increases. The same thing applies to leaving the labor force. When transitioning 
into unemployment, the connection is positive, that is, the higher the level of unemployment - the greater the odds of becoming unemployed, all things being equal. In sum, temporary employees' opportunities for better employment conditions increase during booms and fall during recessions. This can probably be explained by the greater numbers of jobs on offer in upturns, as well as a stronger negotiating power for job seekers allowing them to choose such jobs over temporary employment. This is also in line with findings from previous research (Emmenegger, 2014; Holmlund \& Storrie, 2002; Korpi, 1978).

In summary, this study shows that a temporary contract is not self-evidently a stepping-stone into permanent employment. Close to $40 \%$ of the temporary employed have after 2 years attained a permanent employment, while the rest continue to be in less advantage labor market situations. Our analysis shows that individual attributes are insufficient in explaining the future labor market situation for temporary employees. The effect of a temporary employment has to be related to the employers' motive for using temporary employees. If the employer's motive is to achieve flexibility - reflected in the use of, for example, on-call contracts - it implies lower probability to transit into a permanent contract. Notably, it is the forms of contracts that to a lesser degree works as stepping-stones that have increased in number in Sweden (on-call employees and the group miscellaneous included in the new contract form GTE).

The study also underlines the importance of the institutional context. In this article, we have shown that the general level of unemployment, in addition to how common temporary contracts are in the labor market, also plays a part in the possibility of temporary contracts to function as a stepping-stone. A high level of unemployment forces the job seeker to accept the contractual form, while a high proportion of temporary contracts on the labor market normalizes it. Both these mechanisms can keep employees in temporary contracts.

\section{References}

Auspurg K., Gundert S. (2015): 'Precarious Employment and Bargaining Power: Results of a Factor Survey Analysis'. Zeitschrift für Soziologie, 44(2): 99-117. doi: http://dx.doi.org/ 10.1515/zfsoz-2015-0204.

Baranowska A., Gebel M., Kotowska I. (2011): 'The role of fixed-term contracts at labour market entry in Poland: stepping stones, screening devices, traps or search subsidies?' Work, Employment \& Society 25(4): 777-793. doi: http://dx.doi.org/10.1177/0950017011419705.

Barbieri P. (2009): 'Flexible employment and inequality in Europe'. European Sociological Review, 25(6): 621-628. doi: http://dx.doi.org/10.1093/esr/jcp020.

Berglund, T., Aho, S., Furåker, B., Madsen, P. K., Nergaard, K., Rasmussen, S., Virjo, I. (2010): Labour Market Mobility in Nordic Welfare States. Nordic Council of ministers: TemaNord 2010: 515.

Berton F., Devicienti F., Pacelli L. (2011): 'Are temporary jobs a port of entry into permanent employment? Evidence form matched employer - employee'. International journal of manpower, 32(8): 879-899. doi: http://dx.doi.org/10.1108/01437721111181651.

Bergström, OHåkansson K, Isidorsson T, Walter L (2007). Den nya arbetsmarknaden. Bemanningsbranschens etablering $i$ Sverige. Lund: Academia Adacta.

Booth A., Francesconi M., Frank J. (2002): 'Temporary jobs: Stepping sone or dead ends?' The economic journal, 112(480): 189-213. doi: http://dx.doi.org/10.1111/1468-0297.00043. 
Buddelmeyer H., Wooden M. (2011): 'Transitions out of causal employment: the Australian experience'. Industrial Relations, 50(1): 109-130. doi: http://dx.doi.org/10.1111/j.1468232X.2010.00627.x.

Emmenegger P. (2014): The Power to Dismiss: Trade Unions and the Regulation of Job Security in Western Europe. Published to Oxford Scholarship Online: December 2014. doi: http://dx.doi.org/10.1080/14782804.2015.1067433.

European commission (2015): http://ec.europa.eu/europe2020/pdf/themes/2015/employment protection legislation 20151126.pdf.

Eurostat (2015): Temporary employees as percentage of the total number of employees, by sex and age (\%) [lfsa_etpga], 15-64 years, Last update 20-09-2016, URL: http://appsso. eurostat.ec.europa.eu/nui/show.do? dataset=lfsa etpga\&lang=en.

Gash V. (2008): 'Bridge or Trap? Temporary Workers’ Transitions to Unemployment and to the Standard Employment Contract'. European Sociological Review, 24(5): 651-668. doi: http://dx.doi.org/10.1093/esr/jen027.

Hevenstone D. (2010): 'National Context and Atypical Employment'. International Sociology 25(3): 315-347. doi: http://dx.doi.org/10.1177/0268580909360296.

Holmlund B., Storrie D. (2002): 'Temporary work in turbulent times: the Swedish experience'. The economic journal, 112:480 (F245-F269). doi: http://dx.doi.org/10.1111/14680297.00042.

Holmlund B. (2009): 'The Swedish unemployment experience'. Oxford Review of Economic Policy, 25(1): 109-125. doi: http://dx.doi.org/10.1093/oxrep/grp002.

Hox J. (2002): Multilevel Analysis. Techniques and Applications. Mahwah: Lawrence Erlbaum Associates, Inc., Publishers. doi: http://dx.doi.org/10.4324/9780203852279.

Houseman S. N., (2001): 'Why Employers use Flexible Staffing Arrangements: Evidence From an Establishment Survey'. Industrial and Labor Relations Review, 55(1): 149-79. doi: http://dx.doi.org/10.2307/2696191.

Håkansson, K. (2001) Språngbräda eller segmentering? En longitudinell studie av tidsbegränsat anställda. IFAU: Rapport 2001: 1 .

Kalleberg A. L. (2003): 'Flexible Firms and Labor Market Segmentation: Effects of Workplace Restructuring on Jobs and Workers'. Work and Occupations, 30(2): 154-175. doi: http://dx.doi.org/10.1177/0730888403251683.

Korpi W. (1978): Arbetarklassen i välfärdskapitalismen: arbete, fackförening och politik $i$ Sverige. Stockholm: Prisma i samarbete med Inst. För social forskning.

Korpi T., Levin H. (2001): 'Precarious Footing: Temporary Employment as a Stepping Stone out of Unemployment in Sweden'. Work, Employment and Society, 15, 127-148.

Leschke J. (2009): 'The segmentation potential of non-standard employment: A four-country comparison of mobility pattern'. International journal of manpower, 30(7): 692-715. doi: http://dx.doi.org/10.1108/01437720910997353.

Levin H. (1998): Arbetslöshet, tidsbegränsade anställningar och rörlighet på arbetsmarknaden i 1990-talets Sverige. Institutet för Social Forskning. Licentiatserien 10/1998.

Long J. S. (1997): Regression Models for Categorical and Limited Dependent Variables. Thousand Oaks: Sage Publications.

Mooi-Reci I., Dekker R. (2015): 'Fixed term contracts: Short-term blessings or long-term scars? Empirical findings from the Netherlands 1980-2000'. British Journal of Industrial Relations, 2015(1): 112-135. doi: http://dx.doi.org/10.1111/bjir.12024 10.1111/bjir.12024.

Nergaard K. (2004): Atypisk arbeid Midlertidige ansettelser og deltidsarbeid $i$ Norge. Fafo-rapport 430.

OECD (2004): Employment Outlook. Paris: OECD.

OECD (2014): OECD Employment outlook 2014, OECD publishing. doi: http://dx.doi.org/ 10.1787/empl outlook 2014 eu. 
OECD (2016): Strictness of employment protection - temporary contracts. Dataset: LFS Strictness of EPL - temporary employment. URL: http://stats.oecd.org/Index.aspx?DataSetCode=EPL T, Accessed 30-11-2016.

OECD (2016): Strictness of employment protection - (regular contracts). Dataset: LFS - Strictness of employment protection - individual and collective dismissals (regular contracts. URL: http://stats.oecd.org/Index.aspx?DataSetCode=EPL R, Accessed 30-11-2016.

Reichelts M. (2015): 'Career Progression from Temporary Employment: How Bridge and Trap Functions Differ by Task Complexity'. European Sociological Review, 2015: 1-15. doi: http://dx.doi.org/10.1093/esr/jcw044.

SCB (2015): Utvecklingen av tidsbegränsat anställda. Statisktiska meddelanden, AM 110 SM 1501. Stockholm: Statistiska centralbyrån.

Swedish Code of Statutes (1982:80): Lag om anställningsskydd. [Employment Protections Act] Stockholm: Svensk författningssamling.

Skedinger P. (2010): Hur fungerar arbetsmarknadspolitiken under olika konjunkturlägen? IFN Policy Paper nr 36, 2010. Stockholm: Institutet för näringslivsforkning.

Thelen K. (2014): Varieties of Liberalization and the New Politics of Social Solidarity Cambridge: Cambridge University Press. doi: http://dx.doi.org/10.1017/CBO9781107282001. 